Aquaculture

\title{
Carbon footprint in commercial cultivation of marine shrimp: a case study in southern Brazil
}

\author{
Frank Belettini ${ }^{1 *}$, Walter Quadros Seiffert ${ }^{1}$, Katt Regina Lapa ${ }^{1}$, Felipe do Nascimento Vieira ${ }^{1}$, \\ Carlos Manoel do Espírito Santo ${ }^{1}$, Luis Alejandro Vinatea Arana ${ }^{1}$
}

${ }^{1}$ Universidade Federal de Santa Catarina, Departamento de Aquicultura, Laboratório de Camarões Marinhos, Florianópolis, SC, Brasil.

\begin{abstract}
A life-cycle assessment was conducted during semi-intensive and super-intensive commercial cultivation of marine shrimp from December 2011 to June 2012, considering all phases from the preparation of the nursery to harvesting of the shrimp, to determine the carbon footprints of each process. Inputs and outputs associated to the production of $1 \mathrm{~kg}$ of shrimp were evaluated using the CML-1A baseline method, V3.01 EU25, with Software SimaPro ${ }^{\circledR}$ 8.0.2, to identify the factors of impact that are most relevant to the category global warming, measured in $\mathrm{kg}$ of $\mathrm{CO}_{2}$ eq. The grow-out phase contributed the most to the final results in super-intensive culture, which had a higher carbon footprint, $47.9967 \mathrm{~kg}$ of $\mathrm{CO}_{2}$ eq., which was $1.0042 \mathrm{~kg}$ of $\mathrm{CO}_{2}$ eq. in the semi-intensive culture. The most important impacting factor is the use of electrical energy, which is required to maintain dissolved oxygen and the biofloc particles in suspension in the super-intensive culture and for movement of large volumes of water in the semi-intensive system.
\end{abstract}

Key Words: environmental impact, life-cycle analysis, Litopenaeus vannamei, semi-intensive culture, super-intensive culture

\section{Introduction}

Aquatic foods have high nutritional value, are important as a food source for human nutrition, food security, and generation of income, while contributing to greenhouse gases, although this impact is often underestimated (FAO, 2009).

Climate changes have proven to be an unprecedented challenge, due to the increased atmospheric concentrations of $\mathrm{CO}_{2}$ and other greenhouse gases caused by human activity, and fishing and aquiculture are activities that influence this situation as well as the local and regional management of natural resources (FAO, 2013).

The global environmental impacts caused by aquiculture production systems have awakened increased interest worldwide among consumers, environmental organizations, and industry itself (Ziegler et al., 2013); although aquiculture nurseries can function in such a way

Received: June 21, 2017

Accepted: February 22, 2018

*Corresponding author: frank.belettini@ufsc.br

Copyright (c) 2018 Sociedade Brasileira de Zootecnia. This is an Open Access article distributed under the terms of the Creative Commons Attribution License (http://creativecommons.org/licenses/by/4.0/), which permits unrestricted use, distribution, and reproduction in any medium, provided the original work is properly cited. as to mitigate this impact, by capturing carbon, this has not been considered, according to Boyd (2010).

One way to reduce the impact of aquiculture production systems is by having thorough knowledge of the production system, which allows implementation of corrective measures or adjustment of the technologies used to improve the consumption of natural resources and the disposal of production residues.

The search for environmentally sustainable aquiculture is a constant process that can only be achieved using environmental management tools that identify the potential environmental impacts and factors associated to the production systems, in this case, the production of shrimp in aquiculture systems.

These agro-environmental indicators are quantitative tools that help to evaluate the environmental status and trends, facilitating the identification of effective measures and management solutions, avoiding damage to soil, water, and air and the loss of biodiversity (FAO, 2013).

Conventional shrimp production systems are characterized by extensive flooded areas that require a large volume of water, mainly during the grow-out period because of loss from evaporation and periodical water renewal, while super-intensive systems operate in smaller areas and only replace water lost by evaporation. Therefore, it is logical to believe that a smaller environmental impact 
would be found in the super-intensive systems such as biofloc technology culture systems.

The "carbon footprint" concept measures the total quantity of greenhouse gases directly and indirectly caused by a person, organization, event, or product (Sykes, 2011).

One way to calculate the carbon footprint is using the life-cycle assessment methodology, which measures the potential for global warming in equivalent kilograms of $\mathrm{CO}_{2}$. The objective of this scientific article is to evaluate the carbon footprint during the steps of marine shrimp culture, in a conventional semi-intensive production system and in a super-intensive system with bioflocs, during one commercial production cycle of each method.

\section{Material and Methods}

Semi-intensive and super-intensive commercial culture of marine shrimp Litopenaeus vannamei were conducted in southern Brazil, from December 2011 to June 2012, in Balneário Barra do Sul and Florianópolis, Santa Catarina State $\left(26^{\circ} 32^{\prime} 25.53^{\prime \prime} \mathrm{S}\right.$ and $48^{\circ} 39^{\prime} 05.63^{\prime \prime} \mathrm{W} ; 2^{\circ} 34^{\prime} 55.77^{\prime \prime} \mathrm{S}$ and $48^{\circ} 26^{\prime} 29.42^{\prime \prime} \mathrm{W}$, respectively).

These cultures were conducted in 1.2-ha nurseries with natural soil bottoms and in fiberglass raceways of $50,000 \mathrm{~L}$ (three units each), at densities of 15.5 shrimp $\mathrm{m}^{-2}$ in the semi-intensive system and 184 shrimp $\mathrm{m}^{-2}$ in the super-intensive system, and concluded when the shrimp reached commercial size of $12 \mathrm{~g}$ at harvest.

Two types of marine shrimp production system were evaluated: super-intensive and semi-intensive, each during a complete commercial production cycle, applying the Life Cycle Assessment environmental management methodology, regulated by norms NBR ISO 1440 and NBR ISO 14044 (ABNT, 2009a,b).

The system boundaries involved all the inputs and outputs, from the step for preparation of the cultivation to harvesting of the shrimp (Figure 1).

The functional unit defined for the life-cycle analysis of the production systems was the production of $1 \mathrm{~kg}$ of marine shrimp with average weight of $12 \mathrm{~g}$ at harvest.

The primary data raised for the inventory were obtained directly from the cultivation systems, considering the need for inputs, the use of natural resources and electrical energy consumption, adjusted to the functional unit defined.

To calculate the impact of the agricultural machinery used in preparation of the semi-intensive cultivation nurseries, secondary data were used based on data provided in Ecoinvent ${ }^{\mathbb{}}$, which considers the manufacturing and use of an agricultural tractor, considering its weight $(\mathrm{kg})$ as a function of its useful life and the number of hours it is used during shrimp cultivation.

Inputs to the system included hydrated lime and rice bran - as well as molasses in the super-intensive system - and their impacts were calculated using the data base included in the $\mathrm{SimaPro}^{\circledR}$ 8.0.2 software, appropriately modified to the local conditions of the study.

The impact of the molasses was calculated by using the sugar to molasses conversion index provided by the Sindicato da Indústria do Açúcar e do Álcool no Estado de Pernambuco (2014). The impact of the rice meal was calculated using a production index for rice processing byproducts (Kunrath, 2010).

To calculate the contribution of transportation to the production of greenhouse gases in the production processes, the distance between the location of the production units of the raw materials and the locations of the shrimp cultivation was considered, as well as the technology used in the manufacturing of the motors (EURO 5) found in the transportation vehicles, considering that Brazil has legislation to decrease emissions from fuel consumption.

Secondary data related to the use of electrical generators and harvesting equipment were found in the Ecoinvent ${ }^{\mathbb{B}}$ database and adapted to the study conditions.

The quantity of nutrients, gases, and suspended solids released by the system were determined based on the concentration $\left(\mathrm{mg} \mathrm{L}^{-1}\right)$ of these elements in the residual water, determined by analyses of effluents released by each system.

To determine the contribution of rations to each system, processes for manufacturing $1,000 \mathrm{~kg}$ of rations (with different protein contents), based on inputs and outputs

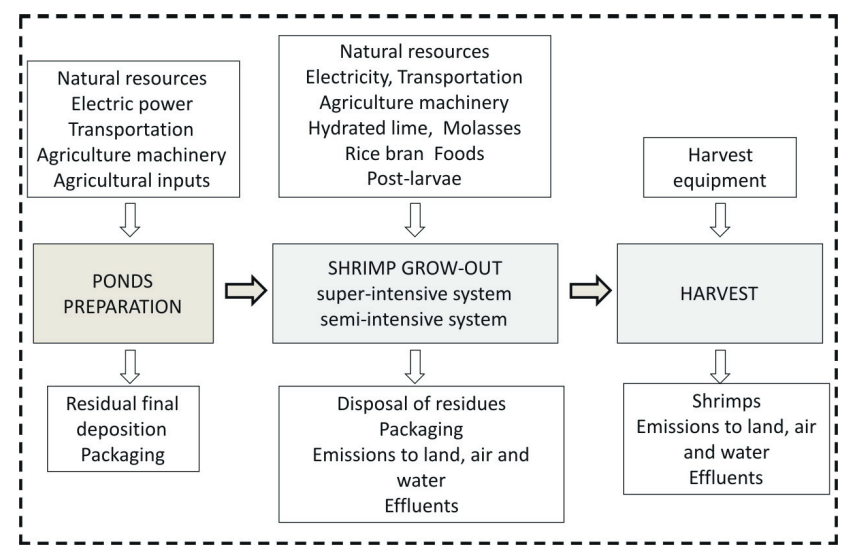

Figure 1 - System boundaries: inputs and outputs evaluated of marine shrimp production in a super-intensive and semi-intensive system. 
described by Sun (2009), were constructed using Software SimaPro ${ }^{\circledR} 8.0 .2$, specific to the modeling and handling of data for life-cycle inventory assessment.

The carbon footprint was determined by calculating the potential for global warming, using the the CML-1A baseline method, V3.01 EU25, with Software SimaPro ${ }^{\circledR}$ 8.0.2, measured in $\mathrm{kg}$ of $\mathrm{CO}_{2}$ eq.

The impact is quantified in this method by identifying and characterizing the substances that cause impacts, for each category of impact, that is, all the inputs and outputs of the production system that contribute to the emission of greenhouse gases in some step of the life-cycle analysis.

\section{Results}

The performance parameters of marine shrimp $L$. vannamei in the systems studied (Table 1) are those normally observed by different authors and that allow economical evaluation of shrimp production.

Larger contributions to the production of greenhouse gases were verified in the grow-out phase of shrimp and the electrical energy was the most relevant impact factor (Table 2).

\section{Discussion}

The performance of the shrimp produced in the systems studied met the standards described for the species (Santos and Mendes, 2007; Scopel et al., 2011; Maia et al., 2012).

A production system can be defined by all the inputs to the system, in this case, the intake, and all the outputs, that is, the product, byproducts, and emissions. All production systems have some impact, and the quantity of the impact

Table 1 - Days of cultivation, final weight, feed conversion factor, survival, specific growth rate, and productivity of marine shrimp, Litopenaeus vannamei, in a commercial cultivation under semi-intensive system and super-intensive system with bioflocs

\begin{tabular}{|c|c|c|c|c|c|c|}
\hline Commercial cultivation system & $\begin{array}{c}\text { Days of } \\
\text { cultivation }\end{array}$ & $\begin{array}{c}\text { Final weight } \\
(\mathrm{g})\end{array}$ & $\begin{array}{l}\text { Feed conversion } \\
\text { factor }\end{array}$ & $\begin{array}{c}\text { Survival } \\
(\%)\end{array}$ & $\begin{array}{l}\text { Specific growth } \\
\text { rate }(\%)\end{array}$ & $\begin{array}{c}\text { Productivity } \\
\left(\mathrm{kg} \mathrm{m}^{-2}\right)\end{array}$ \\
\hline Super-intensive with bioflocs & $78 \pm 0.0$ & $12.5 \pm 1.3$ & $1.50 \pm 0.1$ & $76.9 \pm 6.7$ & $3.44 \pm 0.13$ & $1.8 \pm 0.3$ \\
\hline Semi-intensive & $113 \pm 0.0$ & $12.8 \pm 0.7$ & $1.45 \pm 0.06$ & $83.5 \pm 4.5$ & $1.82 \pm 0.13$ & $0.16 \pm 0.0$ \\
\hline
\end{tabular}

Table 2 - Contribution for $\mathrm{CO}_{2}$ emissions and percentage of impact factors in a commercial cultivation of marine shrimp Litopenaeus vannamei in semi-intensive system and super-intensive system with bioflocs

\begin{tabular}{|c|c|c|c|c|}
\hline \multirow{2}{*}{ Factor for $\mathrm{CO}_{2}$ emission } & \multicolumn{2}{|c|}{ Super-intensive system } & \multicolumn{2}{|c|}{ Semi-intensive system } \\
\hline & $\mathrm{kg} \mathrm{CO}_{2}$ eq. & $\%$ & $\mathrm{~kg} \mathrm{CO}_{2}$ eq. & $\%$ \\
\hline \multicolumn{5}{|c|}{ Preparation of the nursery } \\
\hline Water use & 0.0041 & 0.0086 & 0.3019 & 30.0519 \\
\hline Planing wood & - & - & 0.0009 & 0.0955 \\
\hline Lime & - & - & 0.0141 & 1.4030 \\
\hline Urea & - & - & 0.0386 & 3.8495 \\
\hline Triple superphosphate & - & - & 0.0014 & 0.1422 \\
\hline Agricultural tractor & - & - & 0.0197 & 1.9668 \\
\hline Transportation of inputs & - & - & 0.0425 & 4.2304 \\
\hline \multicolumn{5}{|c|}{ Shrimp cultivation } \\
\hline Shrimp culture & - & - & 0.0170 & 1.6921 \\
\hline Water use & $3.6906 \mathrm{E}-06$ & & 0.4832 & 48.0997 \\
\hline Super-intensive electric power system & 44.5268 & 92.7699 & - & - \\
\hline Electric power generator & 0.0875 & 0.1824 & 0.0009 & 0.0984 \\
\hline Electric power aerators & - & - & 0.0499 & 4.9697 \\
\hline Post-larva - juvenile & 0.0093 & 0.0196 & 0.0084 & 0.8022 \\
\hline Shrimp feed & $3.1683 \mathrm{E}-05$ & 0.0001 & $1.7429 \mathrm{E}-06$ & 0.0002 \\
\hline Hydrated lime & 0.0234 & 0.0488 & - & - \\
\hline Molasses & $3.1828 \mathrm{E}-06$ & 0.0000 & - & - \\
\hline Rice bran & 0.0096 & 0.0200 & - & - \\
\hline Transportation of inputs & 3.3360 & 6.9506 & - & - \\
\hline Agricultural tractor & - & & 0.0055 & 0.5573 \\
\hline \multicolumn{5}{|c|}{ Harvesting of the shrimp } \\
\hline Shrimp harvest & & & 0.022 & 2.1898 \\
\hline Harvesting equipment & - & - & -0.0018 & -0.1876 \\
\hline $\mathrm{kg} \mathrm{CO}_{2}$ eq. total & \multicolumn{2}{|c|}{47.9967} & \multicolumn{2}{|c|}{1.0042} \\
\hline
\end{tabular}


generated varies in life-cycle assessments, according to the functional unit defined for the evaluation.

The knowledge of the impacts associated to manufacturing and production of a certain product is important for management and, thus, for decision-making and improving environmental performance.

The use of the life-cycle assessment methodology in aquiculture is still recent. It is a highly dynamic activity, in which small alterations in handling during the growth of the aquatic organisms can considerably change the result of the animal performance of the species cultivated. This can change the results of the life-cycle analysis inventory, which are directly related to the quantity of functional units quantified in the production system, determining greater or lesser environmental impact.

For this reason, the results of this study were compared with articles related to the theme - but whose results are based on studies in which the boundaries of the production system were different. An effort was thus made to adapt the results obtained by these researchers to the same functional unit defined in this article, during the life-cycle assessment inventory.

It can be seen that most of the factors that contribute to global warming are found in the steps for preparation of the nurseries and in the grow-out phase of shrimp. More than $95 \%$ of the result in the life-cycle analysis is related with this step of the marine shrimp production process in the super-intensive system and just over $55 \%$ of the total in the semi-intensive system.

This is mainly due to the use of electricity in these production systems, although for different purposes. In the super-intensive system, electricity is needed to maintain the dissolved oxygen at normal levels and maintain the bioflocs suspended, while in the semi-intensive system, electricity is used more for pumping the large volumes of water needed, whether to replace loss from evaporation or for the renewal of water during cultivation.

The use of electricity also contributed the most in the phase for preparation of the nurseries in the semi-intensive system; $30 \%$ of the potential for global warming was calculated to be in this step.

Studies by Sun (2009) also found that energy use was the leading producer of greenhouse gases in the aquiculture systems, particularly in intensified cultivation, in which the pumping of water alone was responsible for $59 \%$ of energy consumption in shrimp production in the systems with recirculation evaluated. Mungkung et al. (2006) also found electricity use during shrimp grow-out to be the highest contributor to global warming.
A large portion of the production of greenhouse gases found, regardless of the shrimp production system evaluated, can be attributed to electrical production and supply processes in Brazil, which is responsible for the emission of $115 \mathrm{~kg} \mathrm{CO}_{2} \mathrm{MWh}^{-1}$ (EPE, 2014). According to Piekarski et al. (2013), the highest contribution to the potential for global warming from electricity production refers to the production of energy in hydroelectric plants $(60.03 \%)$, followed by natural gas generators $(17.41 \%)$, those that use petroleum derivatives (13.21\%), and those that burn coal and its derivatives $(8.40 \%)$.

Electrical consumption was also an important factor in the production of greenhouse gases in the production of other species in aquiculture cultivation systems, such as salmon in a closed system (Ayer \& Tyedmers, 2009) and trout in recirculation (d'Orbcastel et al., 2009).

In addition to electrical energy, Cao et al. (2011) found that another factor that contributes to emissions related to global warming in shrimp production systems was the transportation of post-larva, fertilizers, and foods.

As in the studies by Cao et al. (2011), the processes that involve some type of transportation during the life-cycle inventory assessment in this study were considered, and the result of this contribution is mainly associated to the burning of fossil fuels by the transportation vehicles, an activity calculated to contribute emissions of $200 \times 10^{6} \mathrm{t}$ of $\mathrm{CO}_{2}$ (MMA, 2011).

Even if the final results obtained for the carbon footprint in $\mathrm{kg}$ of $\mathrm{CO}_{2}$ eq. in this study $\left(1.0042 \mathrm{~kg}\right.$ of $\mathrm{CO}_{2}$ eq. in semi-intensive culture and $47.9967 \mathrm{~kg}$ of $\mathrm{CO}_{2}$ eq. in super-intensive) are very different when compared with the production of greenhouse gases by other forms of aquiculture for food production [3-15 $\mathrm{kg} \mathrm{CO}_{2}$ eq. (Nijdam et al., 2012)], or by tuna fishing [3.830 $\mathrm{kg} \mathrm{CO}_{2}$ eq.ton ${ }^{-1}$ of tuna landed (Tyedmers and Parker, 2012)], the factors that cause this impact are similar, even considering different system boundaries. For this reason, more studies in this field are needed to better understand the application of the life-cycle assessment methodology in aquiculture, particularly in shrimp cultivation.

\section{Conclusions}

Life-cycle assessment proved to be an efficient methodology for quantifying the carbon footprint in marine shrimp cultivation in different phases of production processes. The factor of impact that most contributes to the result in the systems studied, according to the system boundaries established, is the use of electricity, 
demonstrating that most of the impact associated to the emission of greenhouse gases in marine shrimp cultivation stems from various processes in this production system, which is important information for understanding and managing the entire production process.

\section{Acknowledgments}

The authors would like to thank the staff of the Laboratório de Camarões Marinhos and of the Fazenda Experimental Yakult of the Universidade Federal de Santa Catarina for the support in the conduction of this study. The authors also wish to thank the Fundação de Amparo à Pesquisa e Inovação do Estado de Santa Catarina (FAPESC) for the financial support to the carrying out of the activities.

\section{References}

ABNT - Associação Brasileira de Normas Técnicas. 2009a. NBR ISO 14040. Gestão ambiental - Avaliação do ciclo de vida - Princípios e estrutura. Associação Brasileira de Normas Técnicas, Rio de Janeiro. 21p.

ABNT - Associação Brasileira de Normas Técnicas. 2009b. NBR ISO 14044. Gestão ambiental - Avaliação do ciclo de vida - Requisitos e orientações. Associação Brasileira de Normas Técnicas, Rio de Janeiro. 46p.

Ayer, N. W. and Tyedmers, P. H. 2009. Assessment alternative aquaculture technologies: life cycle assessment of salmonid culture systems in Canada. Journal of Cleaner Production 17:362-373.

Boyd, C. E.; Wood, C. W.; Chaney, P. L. and Queiroz, J. F. 2010. Role of aquaculture pond sediments in sequestration of annual global carbon emissions. Environmental Pollution 158:2537-2540.

Cao, L.; Diana J. S. and Koeleian, G. A. 2011. Life cycle assessment of Chinese shrimp farming systems targeted for export and domestic sales. Environmental Science \& Technology 45:6531-6538.

d'Orbcastel, E. R.; Blancheton, J.-P. and Aubin, J. 2009. Towards environmentally sustainable aquaculture: Comparison between two trout farming systems using Life Cicle Assessment. Aquacultural Engineering 40:113-119.

EPE - Empresa de Pesquisa Energética. 2014. BEN - Balanço Energético Nacional 2014: Relatório síntese 2013. EPE, Rio de Janeiro. Available at: <https://ben.epe.gov.br/downloads/S\%c3\%adntese $\%$ 20do\%20Relat $\%$ c3\%b3rio\%20Final 2014 Web.pdf $>$. Accessed on: Aug. 13, 2014.

FAO - Food and Agriculture Organization of the United Nations. 2009. Climate change implications for fisheries and aquaculture. FAO Fisheries and Aquaculture Technical paper, No. 530. Available at: $<$ http://www.fao.org/docrep/012/i0994e/i0994e00.htm>. Accessed on: Aug. 2, 2014.
FAO - Food and Agriculture Organization of the United Nations. 2013. FAO Statistical Yearbook 2013. World food and agriculture. Roma. Available at: <http://www.fao.org/docrep/018/i3107e/i3107e00.htm>. Accessed on: Nov. 5, 2014.

Kunrath, M. A. 2010. Avaliação nutricional do farelo de arroz desengordurado em suínos nas fases de crescimento e terminação utilizando o método de substituição e a análise de regressão. Dissertação (M.Sc). Universidade Federal do Rio Grande do Sul, Porto Alegre.

Maia E. P.; Modesto A. M.; Brito L. O. and Gálvez, A. O. 2012. Crescimento, sobrevivência e produção do Litopenaeus vannamei cultivado em sistema intensivo. Pesquisa Agropecuária Pernambucana 17:15-19.

MMA - Ministério do Meio Ambiente. 2011. $1^{\circ}$ Inventário Nacional de Emissões Atmosféricas por Veículos Automotores Rodoviários. Available at: <www.mma.gov.br/estruturas/.../163_publicacao2707 2011055200>. Accessed on: Aug. 17, 2014.

Mungkung, R. T.; Udo de Haes, H. A. and Clift, R. 2006. Potentials and limitations of life cycle assessment in setting ecolabelling criteria: A case study of Thai shrimp aquaculture product. International Journal of Life Cycle Assessment 11:55-59.

Nijdam, D.; Rood, T. and Westhoek, H. 2012. The price of protein: Review of land use and carbon footprints from life cycle assessments of animal food products and their substitutes. Food Policy 37:760-770.

Piekarski, C. M.; Francisco A, C.; Luz, L. M.; Bastiani, J. A. and Zocche, L. 2013. Aplicação da ACV na matriz elétrica Brasileira: Uma análise multi cenários em termos de mudança climática, qualidade de ecossistema, saúde humana e recursos. Espacios 34:9-22.

Santos, B. L. S. and Mendes, P. P. 2007. Análise estatística das variáveis de cultivo do camarão-cinza Litopenaeus vannamei (Boone, 1931). Revista Brasileira de Engenharia de Pesca 2:128-142.

Scopel, B. R.; Schveitzer, R.; Seiffert, W. Q.; Pierri, V.; Arantes, R. F.; Vieira, F. N. and Vinatea, L. A. 2011. Substituição da farinha de peixe em dietas para camarões marinhos cultivados em bioflocos. Pesquisa Agropecuária Brasileira 46:928-934.

Sindicato da Indústria do Açúcar e do Álcool no Estado de Pernambuco. 2014. Informações técnicas: Tabela de fatores de conversão entre os principais produtos da agro-indústria da cana-de-açúcar. Available at: $<$ http://www.sindacucar.com.br/cana.php $>$. Accessed on: May 28, 2014.

Sun, W. 2009. Life cycle assessment of indoor recirculating shrimp aquaculture system. Thesis (M.Sc.). University of Michigan, Ann Arbor, Michigan, USA. Available at: $<$ http://deepblue.lib.umich.edu $>$. Accessed on: Jun. 10, 2014.

Sykes, J. 2011. Introdução à pegada de carbono. MMA - Ministério do Meio Ambiente. Available at: <www.mma.gov.br/.../3 introduction to_carbon_footprinting_255pdf $>$. Accessed on: Aug. 18, 2014.

Tyedmers, P. H. and Parker, R. 2012. Fuel consumption and greenhouse gas emissions from global tuna fisheries: A preliminary assessment. ISFF, Technical Report, 2012-03. International Seafood Sustainability Foundation, McLean, Virginia, USA.

Ziegler, F.; Winther, U.; Hognes, E. S.; Emanuelson, A.; Sund, V. and Ellingsen, H. 2013. The carbon footprint of Norwegian seafood products on the global seafood market. Journal of Industrial Ecology 17:103-116. 